\title{
Biblia w oświeceniowych korektach religijności w Polsce XVIII wieku
}

Istotą epoki oświecenia było odkrycie ludzkiego rozumu jako siły mogącej gruntownie zbadać, opisać i przebudować rzeczywistość. Człowiek, wykorzystując władzę myślenia, miał zdobywać się na samodzielność. A to dla luminarzy wieku świateł oznaczało racjonalną krytykę dotychczasowego porządku, zarówno tego ziemskiego, tworzonego przez sposoby rozumowania, układy społeczne i polityczne, naukę, jak i wykraczającego poza ten świat. Przy czym owa krytyka charakteryzowała się niejednorodnością, będąc zróżnicowaną geograficznie oraz pod względem jednostkowych poglądów i postaw. Skutkowało to tym, iż w krajach romańskich oświecenie przybierało postać antykościelną, a nawet antyreligijną. Natomiast w państwach Cesarstwa Niemieckiego życie kościelne potraktowano nie jako obszar, na którym trzeba dokonywać destrukcji, ale jako teren koniecznych przemian ${ }^{1}$. Ich symbolem stały się reformy przeprowadzone przez cesarza austriackiego Józefa II (1780-1790). Nie bacząc na protesty papieża ani prawo kanoniczne modelował on Kościół na podległych mu ziemiach według etatystycznych i utylitarystycznych wzorców myślenia. Władca z rodu Habsburgów, kontynuując dzieło swojej matki cesarzowej Marii Teresy, wprowadził system reform (nazwany józefinizmem), ściśle określając funkcjonowanie Kościoła w monarchii austriackiej. Z czasem system ten stał się synonimem samowoli władzy państwowej w kwestiach wyznaniowych. I kojarzy się powszechnie z kasatami klasztorów i kapituł, narzucaniem duchownym zadań urzędników państwowych, ograni-

\footnotetext{
${ }^{1}$ Zob. J. Kracik, Ewangelicznie i rozumnie, „Znak” 44 (1992) nr 451, s. 57-59.
} 
czaniem pielgrzymek, likwidacją bractw religijnych czy ingerowaniem w liturgię ${ }^{2}$. Rzadziej akcentowane bywa racjonalne zwiększenie liczby parafii oraz diecezji i seminariów, a zarazem stałe ich finansowanie, dbanie o podniesienie poziomu intelektualnego duchowieństwa. Tym samym tkwiący w józefinizmie reformizm zmierzający do odkrywania autentycznej religijności przysłoniony został przez trudne miejscami do przyjęcia założenia i metody ich urzeczywistniania ${ }^{3}$. To zresztą problem dotykający reformatorskich poczynań drugiej połowy XVIII i początku XIX wieku w krajach języka niemieckiego mających na celu odnowę teologii i jej nauczania, liturgii, duszpasterstwa, działań charytatywnych, pobożności wiernych.

Ośrodkami oświeceniowych przemian nastawionych na korygowanie kościelnej rzeczywistości były także dwory bawarski i wirtemberski, liczne klasztory, księstwa duchownych elektorów oraz biskupstwa. Zmiana dokonała się na przełomie XVIII i XIX wieku (decyzje Napoleona doprowadziły do rozbicia organizacji kościelnej w Rzeszy), kiedy to odpowiedzialność za prowadzone dzieło odnowy po biskupach przejęli profesorowie teologii i duszpasterze. Wykorzystując wartościowe postulaty oświecenia, jak racjonalizm, utylitaryzm, humanitaryzm, tolerancja wraz z odkrywaniem zaniedbanej eklezjologii i podjęciem refleksji

${ }^{2}$ Zob. B. Kumor, Józefinizm, [w:] Encyklopedia katolicka, t. 8, Lublin 2000, kol. 176-179. Wobec sprzecznych informacji na temat wyznaczania przez Cesarza-Zakrystianina (tak ironicznie nazywał Józefa II władca Prus Fryderyk II) ilości świec przy ołtarzu w czasie mszy świetej (B. Kumor podaje, iż obowiązywał zakaz palenia więcej niż 6 świec - por. B. Kumor, Józefinizm..., dz. cyt., kol. 178; J. Kracik przeczy, że takie ograniczenie miało miejsce - por. J. Kracik, Ewangelicznie i rozumnie, art. cyt., s. 61) warto wspomnieć o krajowym tego typu zarządzeniu wydanym jednakże nie przez władzę świecką, a kościelną. Bp Michał Jerzy Poniatowski, organizując w diecezji płockiej 40. godzinne nabożeństwo, podawał, aby na ołtarzu przed Sanctissimum paliło się 6 świec lub 4 lampy. W kościołach zasobniejszych materialnie światła miało być więcej, choć przebieg samego nabożeństwa wyróżniać się powinien większą pobożnością, a mniejszymi wydatkami. Pasterz diecezji płockiej wskazał także na przepisy Klemensa XII i Benedykta XIV określające warunki adoracji Najświętszego Sakramentu. O inspiracji pomysłami Józefa II nie było więc mowy. Obaj za to korzystali ze wspólnotowych wzorców właściwych epoce racjonalizmu - zob. M. J. Poniatowski, Rozporządzenie nabożenstwa czterdziestogodzinnego w kościołach diecezji płockiej przez rok cały nieprzerwanego (1779 r.), [w:] Rozporządzenia i pisma pasterskie za rządów J. O. Księcia Jmci Michała Jerzego Poniatowskiego biskupa płockiego, t. 1, Warszawa 1785. s. 386-387.

${ }^{3}$ Zob. J. Kracik, Ewangelicznie i rozumnie, art. cyt., s. 61. 
pastoralnej, dążyli do przezwyciężenia kryzysu tradycyjnej religijności. Jan Michał Sailer, profesor pastoralnej w Landshut ${ }^{4}$, fryburski teolog i pedagog Jan Hirscher ${ }^{5}$, wikariusz generalny arcybiskupa Konstancji Ignacy Wessenberg ${ }^{6}$ to sztandarowi reprezentanci tego środowiska opierający teologię nie na scholastyce, lecz na Piśmie Świętym i patrystyce, w liturgii dostrzegający nie tylko spełnienie obowiązku wobec Stwórcy, ale owocny udział w niej wiernych, postrzegający Kościół bardziej jako wspólnotę niż instytucję.

Z tych trzech wymienionych największe pole do praktycznego działania posiadał Wessenberg, administrując diecezją. Pouczał więc diecezjan, iż wszelkie obrzędy religijne miały ukazywać prawdy wiary i być oceniane ze względu na zbawienie człowieka, a nie dla nich samych. Należało również usunąć ich nieczytelność. Dlatego też wprowadzał w większym zakresie język niemiecki przy szafowaniu sakramentów i udzielaniu błogosławieństw. Poprawiał ryty obrzędów na bardziej zrozumiałe dla wiernych. Dał także szansę uczestnikom mszy świętej aktywniejszego w niej udziału poprzez pieśni mszalne w języku narodowym. Zasadnicza trudność polegała jednak na tym, że Wessenberg, zwolennik episkopalizmu, nie uznawał za konieczne uzyskanie zatwierdzenia przeprowadzonych zmian ze strony Stolicy Apostolskiej.

${ }^{4}$ Jan Michał Sailer (1751-1832), wykładowca, duszpasterz, wpływowy wychowawca zaliczany do pionierów teologii pastoralnej. Nauczał na uniwersytetach w Ingolstadt, Dillingen i Landshut. Na tym ostatnim prowadził zajęcia z teologii moralnej, pastoralnej, pedagogiki, liturgiki, katechetyki. Od 1829 roku biskup Ratyzbony. Autor m.in. trzytomowych Vorlesungen aus der Pastoraltheologie - zob. A. Landersdorfer, Sailer Johann Michael, [w:] Theologische Realenzyklopädie, t. 29, Berlin-New York 1998, s. 638-641.

${ }^{5}$ Jan Baptysta Hirscher (1788-1865), duchowny zaliczany do inspiratorów odnowy teologii moralnej, kaznodziejstwa, liturgii oraz teologii pastoralnej w krajach niemieckojęzycznych i Francji. Proponował m.in. likwidację mszy prywatnych, udzielanie komunii pod dwiema postaciami oraz wprowadzenie do liturgii języka narodowego - zob. F. Greniuk, Hirszer Johann Baptist, [w:] Encyklopedia katolicka, t. 6, Lublin 1993, kol. 934-935.

${ }^{6}$ Ignacy Wessenberg (1774-1860), duchowny, wikariusz generalny Karola Teodora von Dalberga, arcybiskupa Konstancji, reformator życia religijnego w diecezji w nurcie katolickiego oświecenia. Po rozwiązaniu w 1821 roku diecezji w Konstancji urzędnik w rządzie badeńskim. Nie otrzymawszy na skutek papieskiego sprzeciwu arcybiskupstwa we Freiburgu, nie angażował się już w prace kościelne ani polityczne - zob. A. Holzem, Wessenberg Ignaz Heinrich von, [w:] Theologische Realenzyklopädie, t. 35, Berlin-New York 2003, s. 662-667. 
W Rzymie postrzegano go więc (Hirscher doczekał się identycznej oceny) jako osobnika szkodzącego Kościołowi ${ }^{7}$. Przemiany, które zachodziły w świecie (rodzenie się nowoczesności), nie wróżyły, aby to miało ulec zmianie. Diagnoza współczesności skłaniała Kościół do zajęcia pozycji defensywnych, dlatego też poczynania Wessenberga i jemu podobnych oświeceniowych reformatorów nie mogły liczyć na przychylność kurii rzymskiej. Za tym postępowała niemożność spokojnego oglądu spraw i oskarżanie oświecenia o destrukcję religii chrześcijańskiej. Potrzeba było czasu, ażeby powróciły tematy podejmowane kiedyś przez luminarzy katolickiego oświecenia. Po blisko dwóch stuleciach na Soborze Watykańskim II odżyło przekonanie, iż Kościół powinien odpowiadać na aktualne wyzwania, szukać środków przezwyciężenia kryzysu w samym chrześcijaństwie, nie absolutyzować niezmienności jakoby wynikającej z posiadanego depozytu wiary, wreszcie aby w oświeceniu nie widzieć wyłącznie dzieła libertynów, bezbożników i masonów, ale też wysiłek katolików przywracania blasku wartościom ewangelicznym zaniedbanym w epoce wcześniejszej.

W Polsce wiek świateł na podobieństwo niemieckiego wyróżniał się umiarkowaniem, a duchowni stanowili integralnąi wielce znaczącą część elity oświeceniowej. Ta sytuacja sprzyjała przeszczepianiu postulatów epoki na grunt kościelny. Choć zakres, intensywność oraz metodyczność tego działania z różnych względów nie dorównywały zagranicznym wzorcom, to samo działanie nie pozbawione było wspólnych elementów konstytutywnych. Dowartościowanie racjonalności w obszarze sacrum, użyteczność pobudzająca kościelną aktywność, humanitaryzm zaproponowany religijności, tolerancja, optymizm w dawaniu rozwiązań idealnych również tworzyły katolickie oświecenie w Polsce. I tak jak w krajach niemieckojęzycznych, Biblia odzyskiwała właściwe sobie miejsce w teorii i praktyce polskiego Kościoła.

Istotną cechą oświeceniowego modelowania religijności była próba nadania priorytetowego znaczenia Pismu Świętemu w naukach teologicznych oraz w praktycznym głoszeniu wiary. Promotorzy katolickiego oświecenia usiłowali szerzyć znajomość Biblii wśród wiernych. Na fakultetach teologicznych uniwersytetów niemieckich domagano się

${ }^{7}$ Zob. J. Kracik, Ewangelicznie i rozumnie, art. cyt., s. 66-68. 
odnowy teologii w oparciu o tekst natchniony. W dogmatyce zaczęto używać języka biblijnego. W teologii moralnej ta tendencja skutkowała odchodzeniem od kazuistyki, która prowadziła do postrzegania egzystencji chrześcijan z perspektywy wszechobecnego grzechu. Zaczęto za to większą wagę przykładać do nauki o cnotach, w praktykowaniu których pomocne były czerpiące z przekazu biblijnego szkice nauki życia chrześcijańskiego ${ }^{8}$. Odchodzono w ten sposób od modelu wypracowanego w trakcie zmagań z reformacją. A zgodnie z nim urząd nauczycielski Kościoła w reakcji na naukę protestantów o konieczności czytania Pisma Świętego przez każdego człowieka i możliwości osobistej interpretacji z nieufnością podchodził do tłumaczeń świętego tekstu na języki narodowe oraz do lektury indywidualnej. Doktrynalnym wsparciem tej postawy były orzeczenia Soboru Trydenckiego (1545-1563), w których broniono i jasno określono katolicką naukę. Uczestnicy soboru wskazali na Pismo Święte i Tradycję jako źródła objawienia Bożego. Ustalili kanon pism Starego i Nowego Testamentu oraz zdefiniowali autentyczność Wulgaty ${ }^{9}$. Postanowili także: „aby nikt w oparciu o własne sądy dotyczące wiary i moralności należące do gmachu nauki chrześcijańskiej nie dostosowywał Pisma Świętego do swoich opinii wbrew rozumieniu, które utrzymywał i utrzymuje święta Matka Kościół. Do niego należy podawanie prawdziwego sensu i wyjaśnianie Pisma Świętego. Niech też nikt nie komentuje Pisma Świętego wbrew jednomyślnej opinii ojców, nawet gdyby komentarze takie nigdy nie miały być publikowane"10.

${ }^{8}$ Zob. G. Schwaiger, Oświecenie a katolicyzm, „Concilium” 1966 nr 7, s. 381-382.

${ }_{9}$ Ojcom trydenckim chodziło nie tyle o wyjaśnienie źródeł Objawienia wobec nauki protestantów, co o oparcie dzieła soboru na niezachwianej podstawie, tj. Biblii i Tradycji. Przy czym pojęcie tradycji nie zostało na soborze dokładnie określone ani nie wyjaśniono precyzyjnie stosunku pomiędzy Pismem Świętym a Tradycją. Orzeczenie natomiast autentyczności Wulgaty potwierdzało jedynie, że nie zawiera ona błędów wiary, a nie że dosłownie oddaje pierwotny sens danego miejsca w tekście natchnionym. Mylne rozumienie tego zapisu doprowadziło w świecie katolickim do wierzenia, iż Wulgata zawierała Słowo Boże i całą prawdę, więc zbyteczne było sięganie do tekstów pierwotnych - zob. K. Schatz, Sobory powszechne. Punkty zwrotne w historii Kościoła, Kraków 2001, s. 177-180.

${ }^{10}$ Sobór Trydencki (1545-1563), Przyjęcie wydania biblii zwanej Wulgata oraz o sposobie interpretacji Pisma Świętego, 2, [w:] Dokumenty soborów powszechnych. Tekst łaciński i polski, t. 4, układ i oprac. A. Baron, H. Pietras, Kraków 2004. 
Lęk przed interpretacyjną dowolnością płynął z zadawnionego w Kościele przeświadczenia o niebezpieczeństwie związanym z szerszym dostępem do Pisma Świętego. Już bowiem w średniowieczu (w obawie przed sektami) wydawano akty o zasięgu lokalnym ograniczające wiernym korzystanie z Biblii. Wykorzystując te doświadczenia i w obliczu nowych zagrożeń, Pius IV w 1564 roku opublikował reguły dotyczące tłumaczenia i czytania Pisma Świętego. Półtora wieku później w 1713 roku Klemens XI w bulli Unigenitus (potępiając błędy jansenistyczne) odrzucił tezę o konieczności lektury Biblii dla wszystkich. W efekcie kształtowano religijność, która nie promowała Pisma Świętego jako podstawy posłannictwa Kościoła. Dla przeważającej części wiernych oznaczało to, iżjedyny kontakt z tekstami Starego i Nowego Testamentu mogli mieć w trakcie mszy świętej, słuchając ograniczonej ilości tekstów biblijnych ${ }^{11}$. Stąd wysiłek promotorów nurtu katolickiego oświecenia zmierzający do odmiany tego stanu rzeczy i przywrócenia Biblii centralnej pozycji w teologii i duszpasterstwie Kościoła.

Rzeczpospolita w XVIII wieku chyliła się ku upadkowi. Chcąc ochronić państwo przed katastrofą, należało je ustrojowo, gospodarczo i społecznie przebudować. Idee oświecenia padły zatem na podatny grunt, nadając dynamizm dziełu odnowy. Wydatnie włączyli się w nie światli duchowni, których zasługą było dopisanie do wykazu kwestii wymagających koniecznych reform także kościelnych niedomagań. Korzystając z przykładów cudzoziemskich (utrzymywali kontakty z Zachodem poprzez podróże, sprowadzane książki, kontakty z zagranicznymi konfratrami), poprawiali myślenie i postępowanie rodzimej wspólnoty wiernych. I tak jak na Zachodzie, drogą wiodącą do powszechnej szczęśliwości miała być oświata. Na poziomie elementarnym Komisja Edukacji Narodowej (odpowiedzialna za całość szkolnictwa) szkoły połączyła z parafiami. $\mathrm{Na}$ barkach duchownych spoczęła odpowiedzialność za podstawową edukację społeczeństwa. Był to jednak obowiązek dodatkowy, bo pierwszorzędnym zadaniem wciąż pozostawała nauka zasad wiary jakościowo zależna od przygotowania głosicieli. Doskonale dostrzegał ową zależność bp Michał Jerzy Poniatowski, brat królewski. Pasterzując w diecezji płockiej, wydał w 1774 roku nowe ratio studiorum dla seminariów

${ }^{11}$ Zob. J. Kudasiewicz, Biblia w duszpasterstwie, [w:] Encyklopedia katolicka, t. 2, Lublin 1989, kol. 416. 
w Płocku i Pułtusku. Biskup zaprowadzał m.in. egzegezę Pisma Świętego. W trakcie zajęć klerycy musieli posiąść umiejętność interpretacji trudniejszych fragmentów biblijnych, znajomość ogólną i szczegółową Pisma Świętego, a także jak zdobyte wiadomości i samą treść świętych ksiąg przekazywać wiernym oraz jak korzystać z Biblii w kazaniach i rozważaniach ascetycznych. W tym celu scholastyka zastąpiona została wykładem na wzór komentarza opartym na dziełach benedyktyna Antoine'a Calmeta ${ }^{12} \mathrm{~W}$ wymiarze sześciu godzin tygodniowo ${ }^{13}$. W 1781 roku biskup poznański Antoni Okęcki, inspirowany posunięciem bpa Poniatowskiego, wydłużył lata edukacji w seminarium w Poznaniu także do trzech, kładąc m.in. nacisk na studium Pisma Świętego i zalecając te same podręczniki ${ }^{14}$. Natomiast równolegle do działań pasterza diecezji płockiej modernizacji seminarium wileńskiego dokonał bp Ignacy Massalski. W 1774 roku wydał nowy regulamin i ratio studiorum, którym wprowadzał wykłady Pisma Świętego niepołączone z innymi przedmiotami. Massalskiemu zależało na tym, aby w ciągu trzech godzin tygodniowo (zajęcia z Biblii odbywały się na dwóch ostatnich latach w czteroletnim seminarium) klerycy, bazując na posiadanych wiadomościach z teologii dogmatycznej, ,z Pismem św. spoufalali i trudności w rozumieniu jego nie doznawali" ${ }^{15}$. Te inicjatywy obliczone były na danie wiedzy i wierze przyszłych duszpasterzy solidniejszych podstaw biblijnych. Łącznie z pozostałymi reformami uskutecznianymi przez biskupów Poniatowskiego i Massalskiego, czołowych protagonistów katolickiego oświecenia w Polsce, stawały się szansą na wyeliminowanie

${ }^{12}$ Antonie Calmet, imię zakonne Augustyn (1672-1757), biblista, historyk, autor komentarza do całego Pisma Świętego, wyciągu do tego dzieła oraz bardzo popularnego, przekładanego na języki obce Dictionnaire de la Bible. Poprzez swoją twórczość wpłynął na późniejszą egzegezę katolicką i protestancką - zob. F. Gryglewicz, Calmet Antonie, [w:] Encyklopedia katolicka, t. 2, Lublin 1989, kol. 1282.

${ }^{13}$ Zob. M. Grzybowski, Kościelna działalność Michała Jerzego Poniatowskiego biskupa płockiego 1773-1785, Warszawa 1983, s. 140; J. Dukała, „Ratio studiorum” w seminariach diecezjalnych pod zarzadem Misjonarzy 1675-1864, „Nasza Przeszłość” 61 (1984), s. 163.

${ }^{14}$ Zob. J. Dukała, ,Ratio studiorum”..., art. cyt., s. 166.

${ }^{15}$ Cyt. za T. Kasabuła, Ignacy Massalski biskup wileński, Lublin 1998, s. 323; zob. L. Pechnik, Seminaria duchowne w (archi)diecezji wileńskiej do 1939 r., „Studia Teologiczne. Białystok - Drohiczyn - Łomża" 1987-1988, t. 5-6, s. 214-215; T. Krahel, Wileńskie seminarium duchowne po 1652 roku, „Wiadomości Kościelne Archidiecezji w Białymstoku” $10(1984) \mathrm{nr}$ 3, s. 93. 
braków kształcenia teologicznego kadr kościelnych oraz na zasadnicze przeobrażenie życia seminaryjnego.

Źródła nie pozwalają na udzielenie pełnej odpowiedzi, co wyszło z biskupich planów w zetknięciu z rzeczywistością. Raczej poddawała się im z wolna. Niemniej podjęte próby wpisywały się w zmagania wykraczające poza wiek XVIII o uformowanie świadomości biblijnej polskich katolików. Ten długotrwały ogólnokościelny proces zwieńczyło w XX wieku dzieło Soboru Watykańskiego II. Ojcowie tego soboru głosili, iż „wierni winni mieć szeroki dostęp do Pisma św." ${ }^{\text {. }}$. Kaznodziejstwo, katecheza i „wszelkie nauczanie chrześcijańskie powinno być przeniknięte treściami biblijnymi" ${ }^{17}$. Przypominali też, że Pismo Święte zgodnie z Tradycją uznawane jest przez Kościół za „najważniejsze prawidło swej wiary. [...] Trzeba więc, aby całe nauczanie kościelne, tak jak sama religia chrześcijańska, żywiło się i kierowało Pismem św." ${ }^{18}$. Lecz przyczyn tak istotnego zwrotu w podejściu do ksiąg natchnionych upatruje się zazwyczaj w doświadczeniu ruchu biblijnego, nauczaniu papieskim, a przede wszystkim w tradycji patrystycznej. Wkład katolickiego oświecenia w tej materii pozostaje niezauważony, choć bez tego dziedzictwa nauczanie Vaticanum II na temat Bożego objawienia traci na pełnym zrozumieniu.

Kościelni luminarze oświeceniowych przemian nad Wisłą pobudzani utylitaryzmem epoki zmierzali do tego, ażeby biblijne wykształcenie kandydatów na księży znalazło następnie praktyczne zastosowanie w ich pracy duszpasterskiej. Kaznodziejstwo było pierwszym zasadniczym obszarem, na którym duchowny mógł wykazać się zdobytą wiedzą. Dlatego też wspomniani już rządcy diecezji Poniatowski i Massalski, reformując nauczanie seminaryjne, nie pominęli i sztuki głoszenia słowa Bożego. Brat królewski przestrzegał przed bezkrytycznym korzystaniem z pomocy kaznodziejskich oraz uwrażliwiał na to, aby siła dowodowa wygłaszanego Słowa górowała nad elegancją stylu ${ }^{19}$. Klerycy uczyć się mieli tego m.in. z prac kustosza biblioteki ambrozjań-

\footnotetext{
${ }^{16}$ Sobór Watykański II, konst. Dei Verbum, 22.

${ }^{17}$ Tamże, 24.

${ }^{18}$ Tamże, 21.

${ }^{19}$ Zob. M. Grzybowski, Kościelna działalność..., dz. cyt., s. 140.
} 
skiej w Mediolanie Ludwika Antoniego Muratoriego ${ }^{20}$. Książę biskup wileński w ramach wykładów z teologii moralnej uwzględnił zajęcia z homiletyki. Ćwiczenia w komponowaniu i głoszeniu kazań klerycy odbywali wobec sióstr wizytek w każdą niedzielę adwentu i wielkiego postu. Zdolniejsi wygłaszali kazania także w innych kościołach Wilna ${ }^{21}$. Natomiast seminarzyści włocławscy otrzymali od ordynariusza diecezji Józefa Rybińskiego jednoznaczny przekaz: „Ktokolwiek nie trzyma się Pisma św. i Ojców śś. w tej duchowej wymowie nie jest godzien imienia kaznodziei"22. A zgodnie z kanonami epoki tego typu wystąpienie powinno posiadać charakter doktrynalnego wykładu, czerpać z doświadczenia oraz rozważań czysto naturalnych, Boga przedstawiać jako prawodawcę rozpoznawanego poprzez zgłębianie praw natury. W rezultacie w kazaniach oświeceniowych zapanował naturalizm, racjonalizm, historycyzm, antropocentryzm i moralizatorstwo z uszczerbkiem dla kerygmatu chrześcijańskiego, w tym i dla Biblii ${ }^{23}$. Nawet przy jej dowartościowaniu oświeceniowy historycyzm prowokował do traktowania Pisma Świętego jako zbioru wydarzeń i idei z przeszłości ${ }^{24}$. To jednak, co można dostrzec z dystansu mijającego czasu, niezauważone pozostaje w bieżącej chwili. Rodzimi działacze katolickiego oświecenia nie zamierzali zaniedbać ani uszczuplić depozytu pozostawionego ich pieczy. Zwracając uwagę w duszpasterstwie na Pismo Święte, przede wszystkim

${ }^{20}$ Ludwik Antoni Muratori (1672-1750), ksiądz, historyk, pisarz. Przyczynił się do rozwoju nauk historycznych. Np. ukazywał wpływ wędrówek ludów we wczesnym średniowieczu na przemiany cywilizacyjne i społeczne w Europie Zachodniej. Podkreślał rolę racjonalizmu w życiu religijnym, społecznym i politycznym. Domagał się wprowadzenia reform w tych obszarach - zob. R. Sawa, Muratori Ludovico Antonio, [w:] Encyklopedia katolicka, t. 13, Lublin 2009, kol. 508-509. W O porządnym nabożeństwie chrześcian (przetłumaczonym przez pijara M. Tukałło) polski czytelnik mógł odnaleźć takie oto pouczenie Muratoriego: „gdy się trzymać będziemy nabożeństwa, które nam Ewangelia i Kościół najbardziej zaleca, nigdy nie zbłądziemy" (L. A. Muratori, o porządnym nabożeństwie chrześcian, Wilno 1787, s. 588).

${ }^{21}$ Zob. T. Kasabuła, Ignacy Massalski biskup wileński, dz. cyt., s. 322.

${ }^{22}$ J. Rybiński, Ułożenie seminarium w diecezji (anno 1778), [w:] Documenta historia seminaria Wladislaviensis, oprac. S. Chodyński, Varsaviae 1897, s. 108.

${ }^{23}$ Zob. K. Panuś, Zarys historii kaznodziejstwa w Kościele katolickim, cz. 1, Kraków 1999, s. 313-314.

${ }^{24}$ Zob. M. Brzozowski, Biblia w kaznodziejstwie, [w:] Encyklopedia katolicka, t. 2, Lublin 1989, kol. 423. 
zamierzali doprowadzić do odnowy ukształtowanej w okresie baroku religijności wiernych. Za naglącą potrzebę uznali formowanie wiary bardziej przystającej do ewangelii, wyzwolonej z obciążeń minionego czasu, takich jak teatralność, ludyczność, nadmierna materializacja kultu, przesadna cześć świętych, sarmatyzacja.

Działania wyzwolicielskie, np. dotyczące kultu, zdaniem archidiakona krakowskiego Józefa Olechowskiego winny polegać na uczeniu wiernych, „w jakim duchu, która uroczystość z intencji Kościoła obchodzona być powinna, nawet pod imieniem Matki Boskiej i Świętych Pańskich obchodzonych, jedynym i istotnym celem jest uwielbienie i uczczenie Najwyższego Pana, Najłaskawszego Rządcy świata, dobra wszelkiego Dawcy Boga, przez Jezusa Chrystusa Boga Człowieka, Zbawiciela i Pośrednika naszego. Doświadczenie poznać daje, iż wielu się znajduje między wiernymi mniejszego oświecenia, którzy tę z najgłówniejszych prawdę wiary nie tak jasno znają, jak należy, przeto tym usilniej i dokładniej potrzeba ją w umysły i serca wszystkich wpajać" 25 .

Bliźniaczą potrzebę dostrzegał Olechowski także wobec praktyki niezachowywania godności słowa Bożego. Będąc już sufraganem krakowskim (od 1786 roku), zakazał uczniom szkół zbierającym datki wędrowania w niedziele po mieście, kramach i szynkowniach z ewangelią i wodą święconą ${ }^{26}$. Biskup tłumaczył, że nie byli do tego powołani ani zdatni, a i miejsca nawiedzali nieodpowiednie, „bo często opitym ludziom Słowa Bożego uszanować nie mogącym Ewangelię ś. czytają, dla samego tylko nikczemnego zysku"27. Czytanie i przepowiadanie słowa Bożego przynależało duchownym. Nikt inny nie mógł ich w tym wyręczać, jak i od obowiązku ogłaszania i realizowania zarządzeń Olechowskiego i pozostałych oświeconych pasterzy. Dobitnie wyraził to biskup kujawsko-pomorski Józef Rybiński, pouczając swoich księży, „aby w przepowiadaniu Pisma ś. byli rzetelni, i nie naciągali go. Aby

${ }^{25}$ J. Olechowski, Zalecenia z rozkazu J. O. Księcia Jmci Pasterza, „Rubricella Dioecesis Cracoviensis" 1781, k. G.

${ }^{26}$ Zwyczaj ten zaprezentował ks. Jędrzej Kitowicz w Opisie obyczajów za panowania Augusta III, Warszawa 1985, s. 61.

${ }^{27}$ Archiwum Kurii Metropolitalnej w Krakowie: J. Olechowski, Zarządzenie odnośnie zachowania duchowieństwa w czasie kolędy z 26 XII 1786 r., [w:] Książąt biskupów krakowskich pisma na diecezja, k. nlb. 681. 
historyi i innych czynów, które nie są przyjęte za prawdziwe nie przytaczali. Aby prywatnych zdań za artykuły wiary nie opowiadali. Mówiąc o świętych, aby nie wychwalali jednych z poniżeniem drugich"28.

Kłopot polegał jednak na tym, iż oświeceni rządcy diecezji w wydawanych rozporządzeniach, skądinąd słusznych i niezbędnych, nie brali pod rozwagę ograniczeń płynących z przyzwyczajeń, emocji, stopnia świadomości i możliwości percepcji wiernych, a i samych duchownych. Nie bez powodu bp Rybiński przypominał plebanom, ażeby w ich zbiorach bibliotecznych główną pozycję stanowiło Pismo Święte.Jego lektura - pisał biskup - „z chrześcian czyni dobrych rodziców, dobrych przyjaciół, dobrych obywatelów" ${ }^{29}$.W domyśle zaniedbanie czytania świętej księgi takich skutków nie przynosiło, ale wręcz odwrotne. Tym przypomnieniem Rybiński stawał w poprzek nierzadkiemu wówczas zjawisku (o charakterze ogólnokrajowym) nieposiadania Pisma Świętego w parafiach i w zbiorach prywatnych księży. Np. w dekanacie Nowa Góra (diecezja krakowska) w XVII-XVIII wieku, choć pierwsze miejsce w częstotliwości występowania zajmowała Biblia, to i tak zbyt wiele parafii nią nie dysponowało ${ }^{30}$. Nie posiadał jej również komendarz ołtarza św. Anny w kościele parafialnym w Kamienicy (diecezja płocka). Wizytator biskupi w 1781 roku zanotował w sprawozdaniu: „Ks. Lubański ma kaznodziejów tych: Lasselve, Balsama, Wuykowskiego, Theologa Antoine, Pisma Świętego nie ma" ${ }^{31}$. Rzeczonemu komendarzowi do kazań $\mathrm{i}$ katechezy najbardziej przydatna była literatura specjalistyczna, Pismo Święte zgodnie z ówczesną praktyką - mniej. Jej przeobrażanie wymagało nowatorskiego spojrzenia, ale i śmiałości myślenia. Wykazał się nimi ks. Hugo Kołłątaj, który komentarz do niedzielnej perykopy ewangelii przedkładał nad naukę katechizmu (organizowaną w niedzielę przy okazji cotygodniowego zgromadzenia parafian na mszy). Nadto uważał, że znajomość dobrej nowiny podniesie jakość życia społecznego i indywidualnego.

${ }^{28}$ Archiwum Diecezji Włocławskiej: Akta Biskupów Kujawsko-Pomorskich. Akta działalności, sygn. $50\left(60^{\mathrm{b}}\right)$, J. Rybiński, Przepisy dla plebanów i innych kapłanów, s. 189.

${ }^{29}$ Tamże, s. 192.

${ }^{30}$ Zob. J. Kracik, Biblioteki parafialne a prywatne księgozbiory duchowieństwa. Dekanat Nowa Góra w XVII-XVIII wieku, „Archiwa, Biblioteki, i Muzea Kościelne” 32 (1976), s. 261.

${ }^{31}$ M. Grzybowski, Materiały do dziejów ziemi płockiej. Z archiwaliów diecezjalnych płockich XVIII wieku, t. 9, Płock 1998, s. 169. 
Przekonania te zawarł w szczegółowej instrukcji z 1779 roku dla swojego zastępcy na probostwie w Krzyżanowicach. Wyjaśniał i nakazywał w niej: „Ewangelia Jezusa Chrystusa to najświętsze prawa nasze, ludowi znajoma być powinna. Kościół każe ją czytać co niedziela na ten koniec, a zatem starajmy się, żeby ludzie w niej smakowali. Opuśćmy raczej katechizm przez pytania, jeżeli na to czas nie wystarczy, a nie opuszczajmy nigdy wytłumaczyć przeczytanej Ewangelii, nie wybiegając daleko własnymi myślami w prostocie opowiadania to, co nakazał lub radził Chrystus, jakie czynił dobrodziejstwa, lecząc lub uzdrawiając nędzne i cuda łaski swej okazując, gdzie się znajdował, którego czasu w roku, którego roku życia swojego”. Wierni posiadłszy tę wiedzę „byliby koniecznie w obyczajach łagodniejsi, wierniejsi dla panów, użyteczniejsi sami dla siebie, szczęśliwsi i lepsi”"32. Projekt zafundowany gromadzie krzyżanowickiej uczynienia z niej modelowej wspólnoty zakończył się w 1784 roku wraz z zamianą przez Kołłątaja dotychczasowego beneficjum na pińczowskie i w Koniuszy koło Proszowic. Następcy autora Stanu oświecenia w Polsce, wnioskując z poprawek, jakie wprowadzili w architekturze i wystroju kościoła wystawionego przez poprzednika w stylu klasycystycznym, wracali do starych, sprawdzonych wzorców prowadzenia parafii ${ }^{3}$. Stąd wątpliwe, ażeby w centrum pasterskiej działalności stawiali uczenie ludzi „smakowania Ewangelii” - postulat właściwy oświeceniowym reformatorom kościelnej rzeczywistości.

Była to jedna $\mathrm{z}$ konsekwencji elitarności kultury racjonalizmu. Większość społeczeństwa nie posiadała do niej dostępu. Nie inaczej prezentowały się kościelne realia. Krajowi promotorzy katolickiego oświecenia z założeniami i działaniem niesionym przez ten nurt stawali wobec mas wiernych nastawionych na umacnianie religijnego stanu posiadania postrzeganego jako niezmienny. $Z$ reguły duchowni chętnie stan ten konserwowali, czego nie chcieli zaakceptować oświeceni. Za niezwykle istotne uznawali więc odpowiednie formowanie duszpasterzy, z biblijnym włącznie.

Ambitne plany i oczekiwania względem kleru prowadziły do powstania obrazu przykładowego oświeceniowego księdza. Jedną z jego cech było

${ }^{32}$ H. Kołłątaj, Dyspozycja do kościoła krzyżanowickiego, [w:] Wiek XIX. Prace ofiarowane Stefanowi Kieniewiczowi w 60 rocznice urodzin, Warszawa 1976, s. 57-58.

${ }^{33}$ Zob. E. Rostworowski, Ksiądz pleban Kołtątaj, [w:] Wiek XIX..., dz. cyt., s. 60-63. 
posługiwanie się Pismem Świętym w kierowaniu parafią. Lansowano ten przykład nie tylko w oficjalnych pismach zwierzchności diecezjalnej i tekstach co światlejszych duchownych, ale także w utworach literackich. W Panu Podstolim biskupa warmińskiego Ignacego Krasickiego pleban w konstruowaniu kazań korzystał tylko z tekstów biblijnych i doktorów Kościoła. Ewangelię wyjaśniał rzetelnie. Czerpiąc z niej, zachęcał słuchaczy do wypełniania przykazania miłości Boga i bliźniego ${ }^{34}$. Ksiądz pleban z książki biskupa inflanckiego Józefa Kossakowskiego prezentował identyczną ewangeliczną postawę, choć Kossakowski wprost o Piśmie Świętym w swym dziele nie pisa ${ }^{35}$. Przymioty idealnego oświeceniowego pasterza dusz otrzymał także bohater pracy Jana Sailera ks. Ignacy Heggelin. W przepowiadaniu trzymał się ewangelii, tak jak i w życiu osobistym. Zachęcał do tego też swoich parafian. Np. narzeczonych przygotowujących się do sakramentu małżeństwa pouczał: „Czytajcie w niedzielę przynajmniej nim do stołu siądziecie, jaki rozdział z ewangelii” ${ }^{36}$. Książka Sailera wydana w języku polskim w okresie późnego oświecenia, tj. w 1821 roku, wzmacniała paradygmat księdza wieku świateł wiernie i chętnie używającego Biblii na ambonie dla dobra duchowego oraz w pracy dla pożytku doczesnego swoich podopiecznych. A zarazem wzmacniała świeckich w przez wieki wypracowanej pozie - wyłącznie odbiorców.

Oświeceniowe dążenia w krajowym wydaniu przywracania Biblii należnego jej statusu nie zakładały aktywności wiernych. 0 ich samodzielnej lekturze Starego i Nowego Testamentu nie było wzmianek. Zachęta zawarta w pracy Sailera do czytania rozdziału Ewangelii $\mathrm{w}$ domu przed niedzielnym posiłkiem $\mathrm{w}$ warunkach polskich odbiegała od normy. Nawet gdy bp Poniatowski wyznaczał fragmenty Pisma Świętego do przeczytania na spotkaniach zakładanego po parafiach Bractwa Miłosierdzia, to i tak posiedzenie brackie miało odbywać się z udziałem duchownego ${ }^{37}$. Ta zasada miała jeszcze długo funkcjonować.

${ }^{34}$ Zob. I. Krasicki, Pan Podstoli, oprac. J. Krzyżanowski, Kraków 1927, s. 24.

${ }^{35}$ Zob. J. Kossakowski, Ksiądz Pleban, Warszawa 1786.

${ }^{36}$ J. M. Sailer, Ksiądz Pleban, czyli wizerunek dobrego dusz pasterza, Ignacego Walentego Heggelin, plebana w Warthauzie, Lwów 1821, s. 55, 92.

${ }^{37}$ Zob. M. J. Poniatowski, Ustanowienie Bractwa Miłosierdzia po parafiach $w$ archidiecezji gnieźnieńskiej, Łowicz 1786. Wcześniej bp Poniatowski powołał do istnienia Bractwo 
Upadek Rzeczypospolitej i uzależnienie Kościoła od różnych wyznaniowo mocarstw zaborczych z absolutystyczną władzą nie sprzyjały rozwijaniu oświeceniowych projektów. Poddawana korekcie w epoce rozumu swoiście przeżywana pobożność i obyczaj rugowane przez zaborców urastały do rangi narodowych wartości, które należało chronić. Spór między katolicyzmem sarmackim a oświeconym nabrał nowego wymiaru. Na niekorzyść tego drugiego, w tym i dla przywracania Biblii odpowiedniego znaczenia w Kościele.

Kraków

KS. RAFAE SZCZUROWSKI

\section{Słowa kluczowe}

Pismo Święte, katolicyzm, oświecenie, religijność, redakcja, Polska, XVIII wiek

\section{Summary}

Bible in the Enlightenment's corrections of religiosity

One of the most important elements of the Enlightenment era in the 18th century Poland was introduction of the Bible. Polish as well as German Enlightenment was characterized by moderation and was conducive to implementing ideals of the epoch in the Catholic Church. Enlightenment promoted rationality, humanitarianism, tolerance and optimism. It also attempted to promote the Bible. Catholic Enlightenment strove to form ministry based on the Word of God and promote its importance among the faithful. Therefore the Old and New Testament exegesis were introduced into the seminary education. During homiletic studies, prospective preachers were trained how to use the Bible and the writings of the Church Fathers in the most efficient manner. All of the above led to the emergence of a model of a priest who willingly and accurately used the Holy Book for the spiritual enrichment of the faithful. However the involvement of laity in restoring the importance of the Bible was not foreseen.

\section{Keywords}

Holy Scripture, Catholicism, Enlightenment, religiosity, editing, Poland, 18th century

Miłosierdzia w diecezji płockiej i krakowskiej, wdrażając te same przepisy organizacyjne. 